\title{
Removal of Malathion from Aqueous Solutions and Waste Water Using Fly Ash
}

\author{
Vinay K. Singh ${ }^{1}$, Ravi S. Singh ${ }^{1}$, Prem N. Tiwari ${ }^{2}$, Jai K. Singh ${ }^{2}$, Fethiye Gode ${ }^{3}$, Yogesh C. Sharma ${ }^{4}$ \\ ${ }^{1}$ Department of Chemistry, Hemvati Nandan Bahuguna Post Graduate College, Allahabad, India \\ ${ }^{2}$ Department of Chemical Engineering \& Technology, Institute of Technology, Banaras Hindu University, Varanasi, India \\ ${ }^{3}$ Department of Chemistry, Süleyman Demirel University, Isparta, Turkey \\ ${ }^{4}$ Department of Applied Chemistry, Institute of technology, Banaras Hindu University, Varanasi, India \\ E-mail: ysharma.apc@itbu.ac.in \\ Received July 24, 2009; revised August 14, 2009; accepted October 28, 2009
}

\begin{abstract}
Fly ash, obtained from a thermal power plant, Anpara, Sonebhadra, India has been used as an effective adsorbent for the removal of malathion from aqueous solutions. The time required to attain equilibrium was found to increase from 40 to 60 minutes as the initial malathion concentration increases from 1 to $10 \mathrm{mg} / \mathrm{L}$. The optimum $\mathrm{pH}$ value for adsorption was 4.50. The removal of malathion increased by increasing the temperature indicating endothermic nature of removal process. The fly ash exhibited first order rate kinetics and followed both Langmuir and Freundlich isotherm models. Endothermic nature of adsorption process was further supported from increasing values of Langmuir and Freundlich constants with increase in temperature. The adsorbent can be used as an economical product for the removal of malathion from wastewater also. A comparison of the adsorption capacity of fly ash with other adsorbents shows that fly ash can be used for the removal of malathion from aqueous solutions.
\end{abstract}

Keywords: Adsorption, Wastewater, Removal, Fly Ash, Malathion

\section{Introduction}

Pesticides are being used by human beings to protect crops since ages. Since 19th century and onwards the world wide production of pesticides has increased manifold because of increasing population and requirement of foodgrains. In agricultural practices these are used as insecticides, weedicides, fungicides, and herbicides. Part of them is also used to control diseases like malaria, filariasis, dengue, cholera, and Japanese encephalitis. They are also applied in industries to control vegetation, in forests and factory sites, for fumigation of buildings, ships etc. According to an estimate the pests, if not controlled, can damage about $30 \%$ of total world crops production and may pose a serious food problem to the ever increasing world population. In India the production of basic pesticides commenced in 1952 as Benzene Hexa Chloride (BHC) followed by DDT and in mid-nineties, the net production of pesticide was approximately 85,000 metric tones.

Pesticides are toxic chemicals. Many of the insecticides such as DDT, deildrin, heptachlor, and aldrin have been reported to be bioaccumulated in blood, milk, and tissues and in food commodities [1-3]. Excessive use of pesticides has resulted in polluting the surface and ground waters [4-6]. Poison information center in National School of Occupational Health (NIOH), Ahmadabad, India, has reported that organophosphorous compounds are responsible for maximum number of poisoning (73\%) among all agricultural pesticides [7]. Patients of acute organophosphorus poisoning have been reported to suffer from problems like vomiting, nausea, miosis, excessive salivation, blurred vision, headache, giddiness, and disturbance in consciousness [8]. In case of malathion, which is one of the widely used organophosphorus pesticide, almost all the effects observed are due to its active metabolite malaxon [9] on the nervous system or is secondary to its primary action. Malathion is moderately toxic to birds and has a wide range of toxicity in fish and other aquatic invertebrates and is highly toxic to honeybees [10]. Because of toxic and hazardous nature, removal of pesticides from water and wastewater has been concern of scientists and activated charcoal is the most commonly used adsorbent for emoving pesticide residue from contaminated water [11-13]. Materials investigated as adsorbents for pesticides includes: Char- 
coal from agro waste [14], straw [15], date and olive stones, wood chips/corn cob [16], lignocellulosic substrate from agro industry [17], bark [18], baggasse fly ash [19] and coal fly ash [20]. Fly ash has also been used reported for removal of metallic species [21]. Out of most of the non-conventional adsorbents used for the removal of pesticides, fly ash has advantage over others as it is basically a waste of thermal power plants and is recognized as a nuisance for environment and industry. In the present study removal of malathion from water has been taken up by batch adsorption technique using fly ash as the adsorbent material.

\section{Material and Methods}

\subsection{Materials}

Fly ash was obtained from Anpara thermal power plant, Sonebhadra, India. It is generated from the combustion of powdered coal or lignite and collected from flue gas of pulverized fuel fired boilers with the help of electrostatic precipitation. Its surface area and pore volume was determined by B.E.T. method using low temperature $\mathrm{N}_{2}$ adsorption and particle size was determined by sieve method. Physical and chemical characterization of fly ash is shown in Tables 1 and 2. I.R. spectra of the adsorbent was also carried out and the peaks indicate presence of Al-O, Si-O and Fe-O bonding.

Table 1. Characterization of adsorbent.

\begin{tabular}{lc}
\hline \multicolumn{1}{c}{ Constituent/physical properties } & Percent range \\
\hline Silico $\left(\mathrm{SiO}_{2}\right)$ & $49-61$ \\
Alumina $\left(\mathrm{Al}_{2} \mathrm{O}_{3}\right)$ & $16-24$ \\
Iron Oxide $\left(\mathrm{Fe}_{2} \mathrm{O}_{3}\right)$ & $4-10$ \\
Sodium Oxide $\left(\mathrm{Na}_{2} \mathrm{O}\right)$ & $2-3$ \\
Calcium Oxide $(\mathrm{CaO})$ & $1-2$ \\
Magnesium Oxide $(\mathrm{MgO})$ & $1-2$ \\
Sulphar Tri Oxide $\left(\mathrm{SO}_{3}\right)$ & $0.1-2$ \\
Surface area & $143.6 \mathrm{~m}^{2} / \mathrm{gm}$ \\
Pore volume & $0.1247 \mathrm{~cm}^{2} / \mathrm{g}$ \\
Particle Size & $149 \mu \mathrm{m}$ \\
\hline
\end{tabular}

Table 2. Important I.R. bands of fly ash along with their probable assignment.

\begin{tabular}{cc}
\hline Band Position $\left(\mathrm{cm}^{-1}\right)$ & Assignments \\
\hline 796.9 & Aromatic (C-H) Bonding \\
900.5 & Al-O \\
1097 & Si-O \\
2348.2 & Fe-OH \\
3568.0 & O-H \\
3650 & O-H \\
3855.0 & O-H \\
\hline
\end{tabular}

All chemicals were of analytical grade. Sodium ethoxide and rhodamine $6 \mathrm{G}$ was obtained from LOBA chemical, Mumbai, India. Malathion was obtained from northern minerals Ltd. New Delhi, India.

\subsection{Equipments}

pH was measured by $\mathrm{pH}$ meter (ELISCO L 1612), surface area and porosity were measured by surface area and porosity analyzer (ASAP-2020). Malathion concentration was determined by flourescence spectrophotometer (CARRYECLKIPSE).

\subsection{Methods}

Malathion solution was prepared by dissolving a known quantity of malathion in double-distilled water. Standard base of $0.1 \mathrm{M} \mathrm{NaOH}$ and acid of $0.1 \mathrm{M} \mathrm{HCl}$ solutions were used for $\mathrm{pH}$ adjustment. Temperature was controlled by keeping the mixtures in a water circulation bath whose temperature varied within $\pm 0.2^{\circ} \mathrm{C}$. To maintain a constant thermal state, the bottles were first placed into the temperature controlled bath for about $0.5 \mathrm{~h}$ prior to the start of the experiments. All experiments were replicated and the average values were taken in the data analysis.

Kinetic adsorption experiments were carried out to establish the effect of time on the adsorption process and to determine the rate of adsorption for malathion removal as affected by $\mathrm{pH}$ and temperature. The general experimental procedures are described as follows:

1) prepare one liter solution containing a certain amount of malathion in a glass bottle; 2) agitate these solutions on a mechanical stirrer at $140 \mathrm{rpm}$; 3) adjust solution $\mathrm{pH}$ to a desired value; 4) add a given amount of the fly ash (7 g/L) into the solution; 5) at the completion of preset time intervals, 6) determine the residual malathion concentration in each of the supernatants. The amount of malathion adsorbed in $\mathrm{mg} / \mathrm{g}$ at contact time $\mathrm{t}$ was calculated as follows:

$$
\mathrm{qt}=(\mathrm{Co}-\mathrm{Ct}) / \mathrm{w}
$$

where $\mathrm{Co}(\mathrm{mg} / \mathrm{L})$ and $\mathrm{Ct}(\mathrm{mg} / \mathrm{L})$ are the initial malathion concentration and the malathion concentration at time $t$, respectively; $\mathrm{w}(\mathrm{g} / \mathrm{L})$ is the fly ash amount in the solution. Equilibrium experiments were performed to establish the adsorption isotherms affected by $\mathrm{pH}$, and temperature. The isotherm studies were conducted by varying the initial malathion concentration at room temperature while the adsorbent was kept at $7 \mathrm{~g} / \mathrm{L}$. Detailed experimental procedures were described as follows: 1) prepare one 2.0 L solution of different malathion concentrations; 2) distribute $100 \mathrm{~mL}$ of solution to a series of $125 \mathrm{~mL}$ glass bottles; 3) adjust initial $\mathrm{pH}$; 4) add a given amount of the 
fly $\operatorname{ash}(7 \mathrm{~g} / \mathrm{L})$ into the solution; 5) shake these bottles on a reciprocal shaker at 140 excursions/min to reach the equilibrium; 6) at the end of shaking separate the adsorbent and the supernatant was collected for determination of malathion concentration.

\subsection{Determination of Malathion Concentration}

$100 \mathrm{~mL}$ standard malathion solution $(20 \mathrm{mg} / \mathrm{L})$ was placed in a seaprating funnel. To this $100 \mathrm{~mL}$ sodium ethoxide $(3 \mathrm{~g} / \mathrm{L})$ was added and the contents were agitated. Distilled water $(10 \mathrm{~mL})$ was added, followed by vigorous shaking. The layers were allowed to separate and the $\mathrm{CCl}_{4}$ layer was discarded. The aqueous layer was washed with $50 \mathrm{~mL}$ of $\mathrm{CCl}_{4}$ and neutralized with $2 \mathrm{M}$ $\mathrm{H}_{2} \mathrm{SO}_{4}$. A $2 \mathrm{~mL}$ aliquot of buffer solution was added followed by $20 \mathrm{~mL}$ of rhodamine $6 \mathrm{G}(0.2 \mathrm{mg} / \mathrm{L})$ and $50 \mathrm{~mL}$ toluene and the mixture was shaken vigorously. The organic layer was collected and dried over anhydrous sodium sulphate; it was then transferred into the spectrofluorimetric cell and the fluorescence was measured at $350 \mathrm{~nm}$. A calibration plot was constructed by plotting the mean fluorescence reading against the concentration of malathion. $50 \%$ emulsifiable concentrate malathion solution $(10 \mathrm{mg} / \mathrm{L})$ was placed in the separating funnel, hydrolysed and then determined as usual.

\section{Results and Discussion}

\subsection{Effect of Concentration}

The effect of initial malathion concentration on removal efficiency of fly ash and time to reach equilibrium was studied over a wide range of malathion concentration $(1-10 \mathrm{mg} / \mathrm{L})$. On changing the initial malathion concentration from $1 \mathrm{mg} / \mathrm{L}$ to $10 \mathrm{mg} / \mathrm{L}$, percent removal decreased from 99 to $90 \%$ at $30^{\circ} \mathrm{C}, \mathrm{pH} 4.50$ and particle size $194 \mu \mathrm{m}$ (Figure 1). It is evident from the figure that adsorption increases with time and attains a maximum value and there after remains constants i.e., equilibrium is achieved. Although percent removal with higher concentration is less, the amount of malathion adsorbed on solid phase (fly ash) is higher than that at lower initial concentrations. It was also observed that as the initial concentration of malathion is increased, more and more time is needed to attain the equilibrium and at an initial malathion concentration of $1 \mathrm{mg} / \mathrm{L}$, the equilibrium time is $40 \mathrm{~min}$ whereas, at a concentration of $10 \mathrm{mg} / \mathrm{L}$ it was $60 \mathrm{~min}$.

\subsection{Effect of pH}

The removal of malathion by fly ash as a function of $\mathrm{pH}$

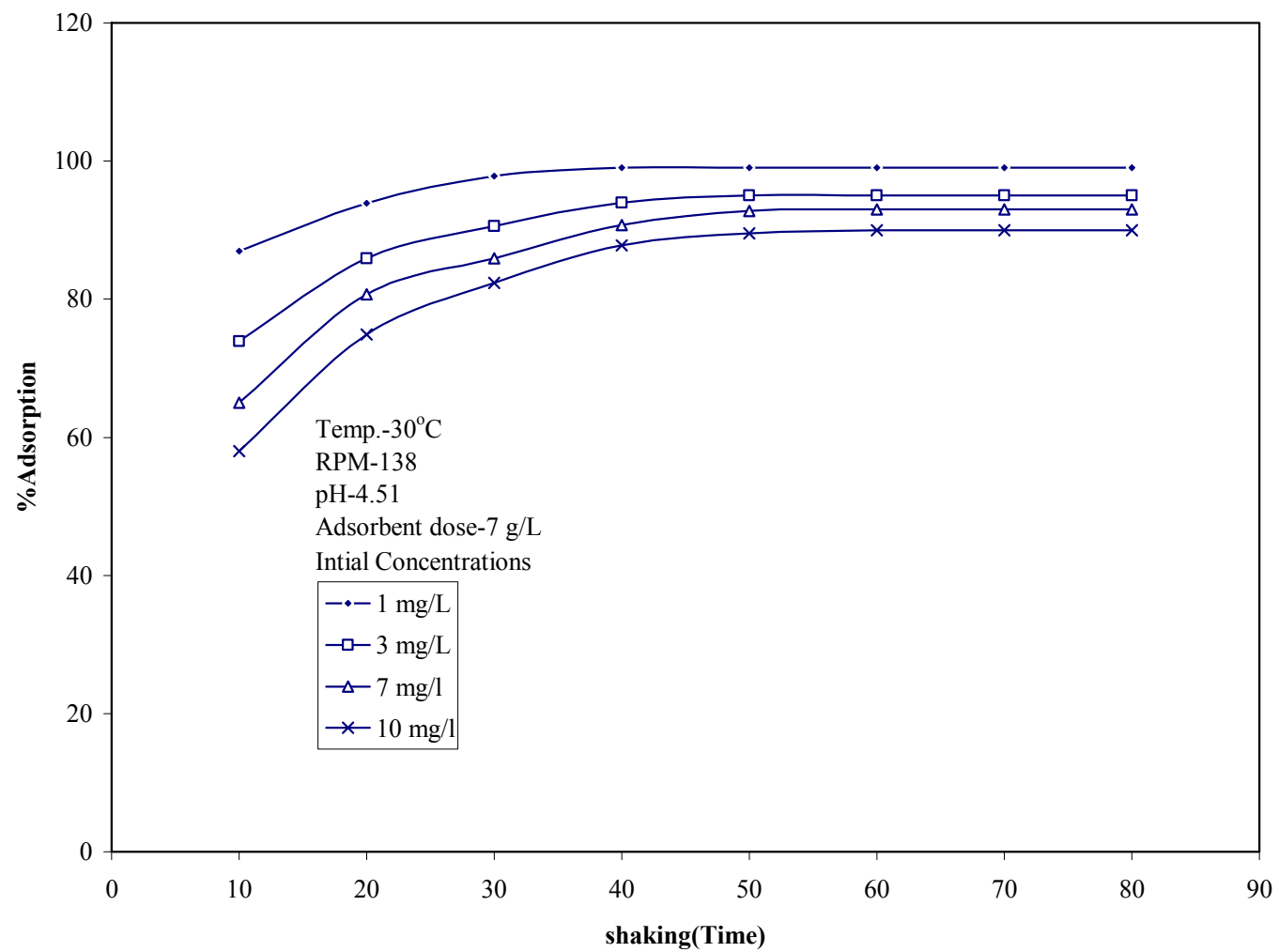

Figure 1. Time variation of adsorption of malathion on fly ash at different initial concentrations. pH: 4.50 , temperature: $30 \pm$ $0.05^{\circ} \mathrm{C}$. 
at initial concentrations of $1 \mathrm{mg} / \mathrm{L}, 5 \mathrm{mg} / \mathrm{L}$ and $10 \mathrm{mg} / \mathrm{L}$ at temperature $30^{\circ} \mathrm{C}$, particle size $149 \mu \mathrm{m}$ was studied and has been shown in Figure 2. The studies were made over 3.0 to $7.0 \mathrm{pH}$ range. It is clear from the figure that for each initial concentration value of malathion, the percent removal increases as $\mathrm{pH}$ rises and after $\mathrm{pH} 4.50$, the percent removal decreases with further increase in $\mathrm{pH}$ value. With initial concentration of $1 \mathrm{mg} / \mathrm{L}$, percent removal at $\mathrm{pH} 3.00$ is $96.1 \%$, at $\mathrm{pH} 4.50$ it is $99 \%$ and at $\mathrm{pH} 7.00$ it is $95.09 \%$. Similarly with initial concentration of $10 \mathrm{mg} / \mathrm{L}$, the percent removal at $\mathrm{pH} 3.00$ was $88.88 \%$, at $\mathrm{pH} 4.50$ it is $90 \%$ and at $\mathrm{pH} 7.00$ percent removal again decreases up to $88 \%$. This clearly shows that the optimum $\mathrm{pH}$ for the present adsorbate-adsorbent system is 4.50 .

\subsection{Adsorption Dynamics}

Study of kinetics of adsorption is very important aspect of adsorption process as it gives an idea of adsorbate uptake rate. This controls the residence time of adsorbate uptake at the solid-solution interface and defines the efficiency of adsorption. For the present system, the adsorption dynamics of removal of malathion was studied by conducting the batch adsorption experiments taking its $50 \mathrm{~mL}$ solution desired concentrations and $7 \mathrm{~g} / \mathrm{L}$ dose of fly ash in a shaking machine operated at a fixed agitation speed (138 rpm), particle size of $149 \mu \mathrm{m}$, at $\mathrm{pH} 4.50$, temperature $30^{\circ} \mathrm{C}$ and initial concentration of $10 \mathrm{mg} / \mathrm{L}$. Lagergren equation [22] was used for the data obtained:

$$
\ln \left(\mathrm{q}_{\mathrm{e}}-\mathrm{q}\right)=\ln \mathrm{q}_{\mathrm{e}}-\mathrm{k}_{\mathrm{a}^{d}} \times \mathrm{t}
$$

where $\mathrm{q}_{\mathrm{e}}$ is the amount of solute adsorbed at equilibrium per unit weight of adsorbent $\left(\mathrm{mg} \cdot \mathrm{g}^{-1}\right)$, and $\mathrm{k}_{\mathrm{ad}}$ is the rate constant of adsorption. The plot of $\ln \left(\mathrm{q}_{\mathrm{e}}-\mathrm{q}\right)$ vs $\mathrm{t}$ (Figure 3) at initial concentration of $10 \mathrm{mg} / \mathrm{L}, \mathrm{pH} 4.50$, particle size $149 \mu \mathrm{m}$ and temperature $30^{\circ} \mathrm{C}$ is linear indicating that the adsorption follows the above equation used for kinetic modeling. The value of $\mathrm{k}_{\mathrm{ad}}$, calculated from the slope of the straight line was $0.075 \mathrm{~min}^{-1}$ (Table 3).

\subsection{Adsorption Isotherm}

The study of adsorption isotherms and evaluation of isotherm constants is very helpful for judging the feasibility of an adsorbate-adsorbent system and for evaluating dose of adsorbent. The equilibrium data for the adsorption of malathion on fly ash at $\mathrm{pH} 4.50$ and different temperatures, follow the rearranged form Langmuir equation [23]:

$$
1 / \mathrm{q}_{\mathrm{e}}=1 / \mathrm{Q}^{0}+1 / \mathrm{bQ} \mathrm{C}^{0} \mathrm{C}_{\mathrm{e}}
$$

where $\mathrm{q}_{\mathrm{e}}$ is the amount of malathion adsorbed at equilibrium $\left(\mathrm{mg} \cdot \mathrm{g}^{-1}\right)$ and $\mathrm{C}_{\mathrm{e}}$ the equilibrium concentration $(\mathrm{mg} / \mathrm{L}), \mathrm{Q}^{0}$ and $\mathrm{b}$ are Langmuir constants which are related to adsorption capacity and apparent heat change

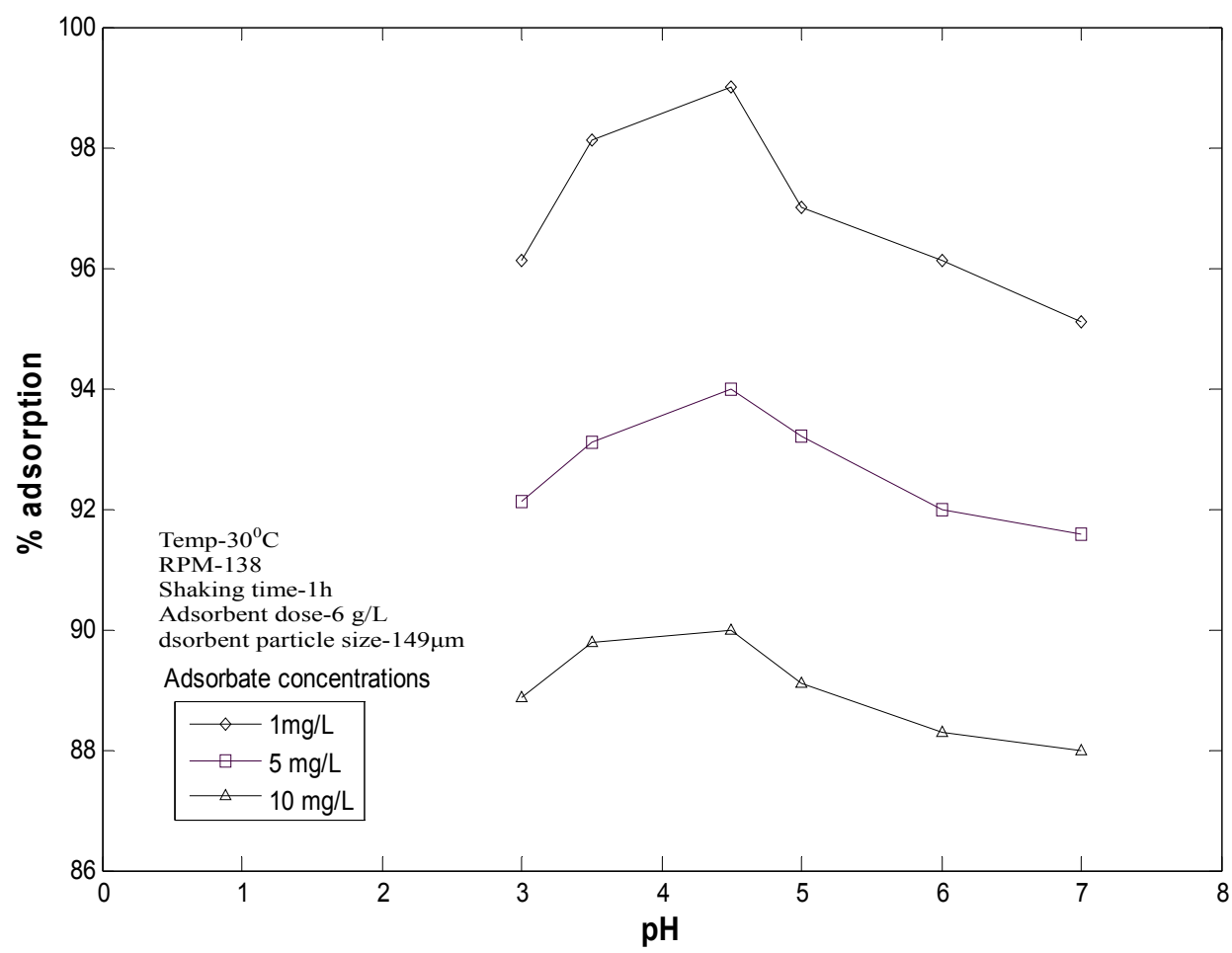

Figure 2. Adsorption of malathion on fly ash at different $\mathrm{pH}$ values. Initial concentrations: $1 \mathrm{mg} / \mathrm{L}, 5 \mathrm{mg} / \mathrm{L} \mathrm{and} 10 \mathrm{mg} / \mathrm{L}$, temperature : $30 \pm 0.05^{\circ} \mathrm{C}$, particle size $: 149 \mu \mathrm{m}$. 


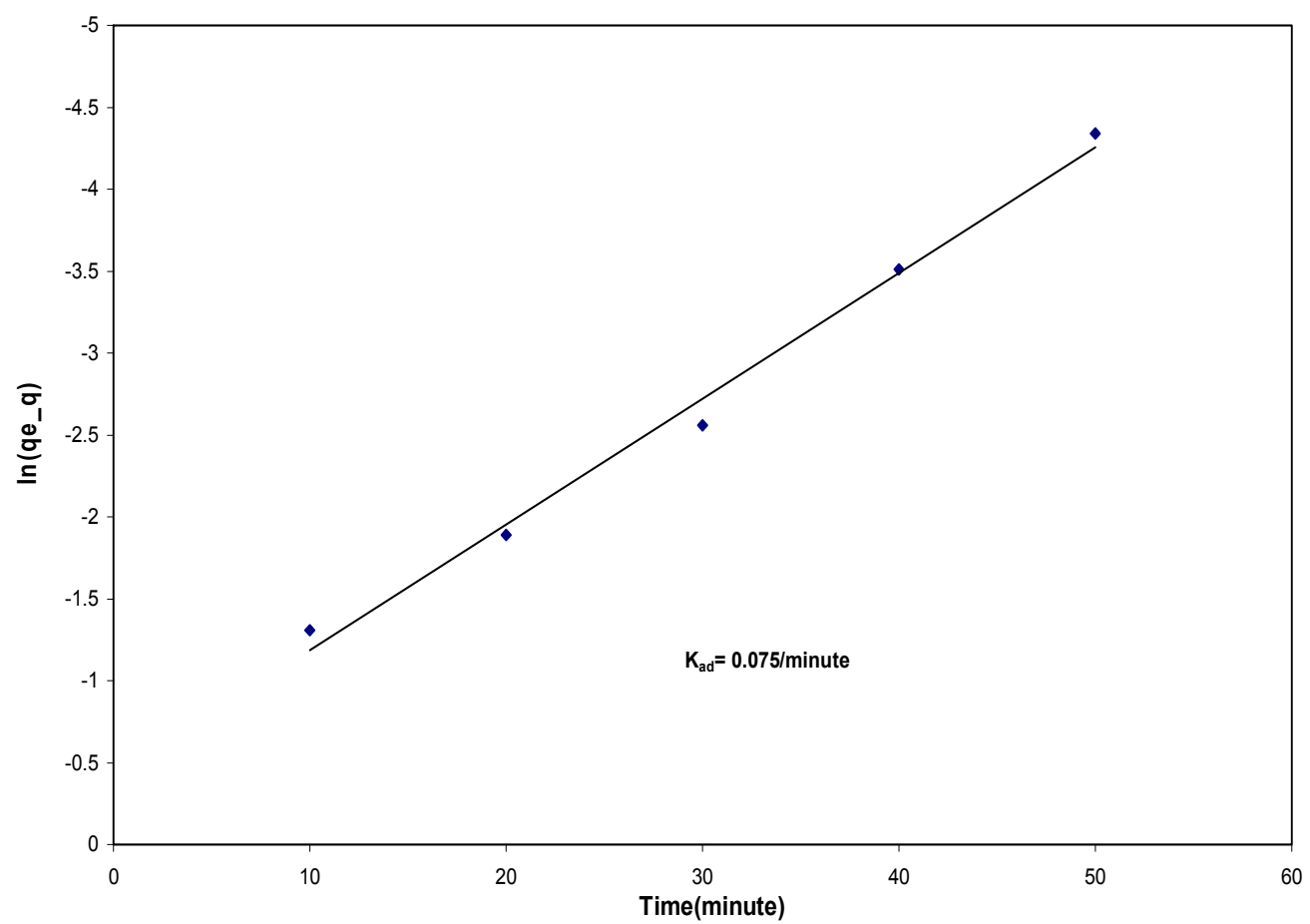

Figure 3. Lagergreen's plot for the removal of malathion by fly ash Initial concentration: $10 \mathrm{mg} / \mathrm{L}$, pH: 4.50, temperature: 30 $\pm 0.05{ }^{\circ} \mathrm{C}$, particle size: $149 \mu \mathrm{m}$, agitation speed: $138 \mathrm{rpm}$.

respectively at different temperatures. The values of $\mathrm{Q}^{0}$ and $b$ were determined from the slopes and intercepts of linear plots of $1 / \mathrm{q}_{\mathrm{e}}$ vs $1 / \mathrm{C}_{\mathrm{e}}$ (Figure 4) and the values have been given in (Table 4).

As (Figure 4) indicates, for a given value of initial concentration, $\mathrm{pH}$ and average particle size of adsorbent, the equilibrium concentration $\mathrm{C}_{\mathrm{e}}$, of adsorbate in solution is higher at lower temperature and it decreases with increasing temperature i.e. the adsorption is favored at

Table 3. Rate constant and enthalpy change $\Delta H$ values.

\begin{tabular}{cc}
\hline Parameters & Values \\
\hline Rate Constant $\left(\mathrm{min}^{-1}\right)$ & 0.075 \\
$\Delta \mathrm{H}\left(\mathrm{kJ} \mathrm{mol}^{-1}\right)$ & +2.537 \\
\hline
\end{tabular}

Table 4. Various constants at different temperatures.

\begin{tabular}{cccc}
\hline & \multicolumn{3}{c}{ Values at different temperatures } \\
$\left( \pm 0.05^{\circ} \mathrm{C}\right)$ \\
\cline { 2 - 4 } Parameters & $35^{\circ} \mathrm{C}$ & $45^{\circ} \mathrm{C}$ & $55^{\circ} \mathrm{C}$ \\
\hline Langmuir constants & & & \\
$\mathrm{b}$ & 6.75 & 7.97 & 15.00 \\
$\mathrm{Q}^{0}$ & 0.726 & 0.850 & 0.99 \\
Freundlich constants & & & \\
$\mathrm{K}_{\mathrm{f}}$ & 1.09 & 1.55 & 1.85 \\
$\mathrm{n}$ & 15.56 & 17.66 & 19.75 \\
\hline
\end{tabular}

higher temperature. This is supported from increase in $\mathrm{Q}^{0}$ and $b$ values with increase in temperature (Table 4).

The applicability of Langmuir isotherm in the present system indicates the mono layer coverage of malathion on the outer surface of the adsorbent. Similar results for other adsorbate-adsorbent systems have been reported earlier [24-28].

The Freundlich isotherm, commonly used for adsorption from aqueous system was also found to be applicable

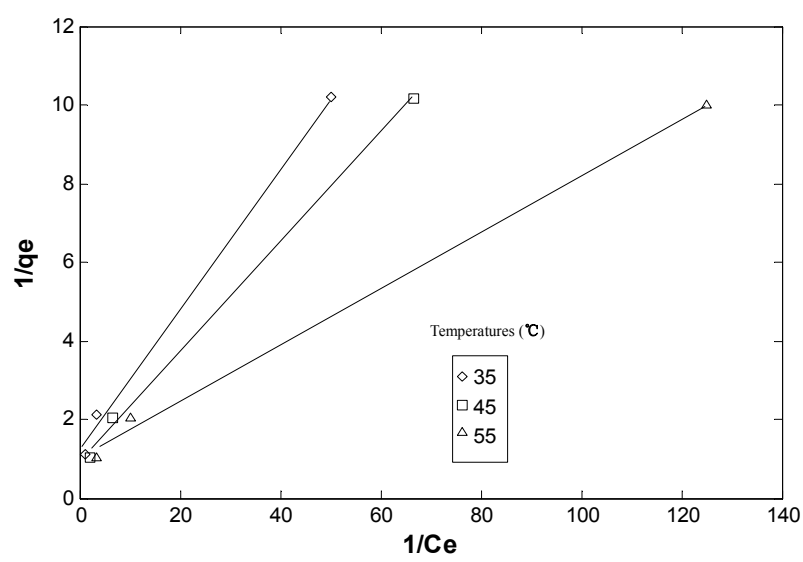

Figure 4. Langmuar isotherm for adsorption of malathion on fly ash at different temperatures. $\mathrm{pH}$ : 4.50, partical size: $149 \mu \mathrm{m}$, agitation speed: $138 \mathrm{rpm}$, contact time: $90 \mathrm{~min}$. agitation speed: $138 \mathrm{rpm}$. 
for the present adsorbate-adsorbent system. Linear form of Frendulich isotherm is indicated as follows [29]:

$$
\log \mathrm{q}_{\mathrm{e}}=\log \mathrm{K}_{\mathrm{f}}+1 / \mathrm{n} \cdot \log \mathrm{C}_{\mathrm{e}}
$$

where $K_{f}$ and $n$ are Freundlich constants and their values were obtained (Table 4) from the plot of $\log q_{e} v s \quad \log C_{e}$ (Figure 5). Values of $\mathrm{K}_{\mathrm{f}}$ and $\mathrm{n}$ both are roughly related to Langmuir's constants $\mathrm{Q}^{0}$ and $\mathrm{b}$ and like $\mathrm{Q}^{0}$ and $\mathrm{b}$ values the values of $\mathrm{K}_{\mathrm{f}}$ and $\mathrm{n}$ also increase with increase in temperature i.e. adsorption increases with rise in temperature.

\subsection{Effect of Temperature}

The adsorption of malathion by fly ash was found to increase from 90 to $97.5 \%$ by increasing temperature from 35 to $55^{\circ} \mathrm{C}$ (Figure 6) at $\mathrm{pH} 4.50$, initial concentration 10 $\mathrm{mg} / \mathrm{L}$, particle size $149 \mu \mathrm{m}$, indicating that adsorption is endothermic. The endothermic nature of adsorption is supported by thermodynamic parameter $\Delta \mathrm{H}$ calculated from the equation [30]:

$$
\mathrm{b}=\mathrm{b}^{\prime}-\mathrm{e}^{-\Delta \mathrm{oH} / \mathrm{RT}}
$$

where b is Langmuir's constant, b' is another constant and $\Delta \mathrm{H}$ is enthalpy change, $\mathrm{T}$ is temperature in Kelvin and $\mathrm{R}$ is gas constant.

Linear form of Equation (4) can be written as:

$$
\operatorname{lnb}=\ln b^{\prime}-\Delta \mathrm{H} / \mathrm{RT}
$$

On plotting a graph between lnb vs $1 / \mathrm{T}$ (Figure 7), a straight line is obtained from slope of which value of $\Delta \mathrm{H}$ has been calculated (Table 3). The positive value of $\Delta \mathrm{H}$ shows that adsorption is favored with increase in temperature.

\section{Conclusions}

From the studies it becomes clear that fly ash has potential for removal of malathion from aqueous solutions. Application of fly ash serves two purposes. One, fly ash is a waste material and poses disposal problems, and two, the removal of malathion, a toxic substance from environment view point. Higher (\%) removal of malathion

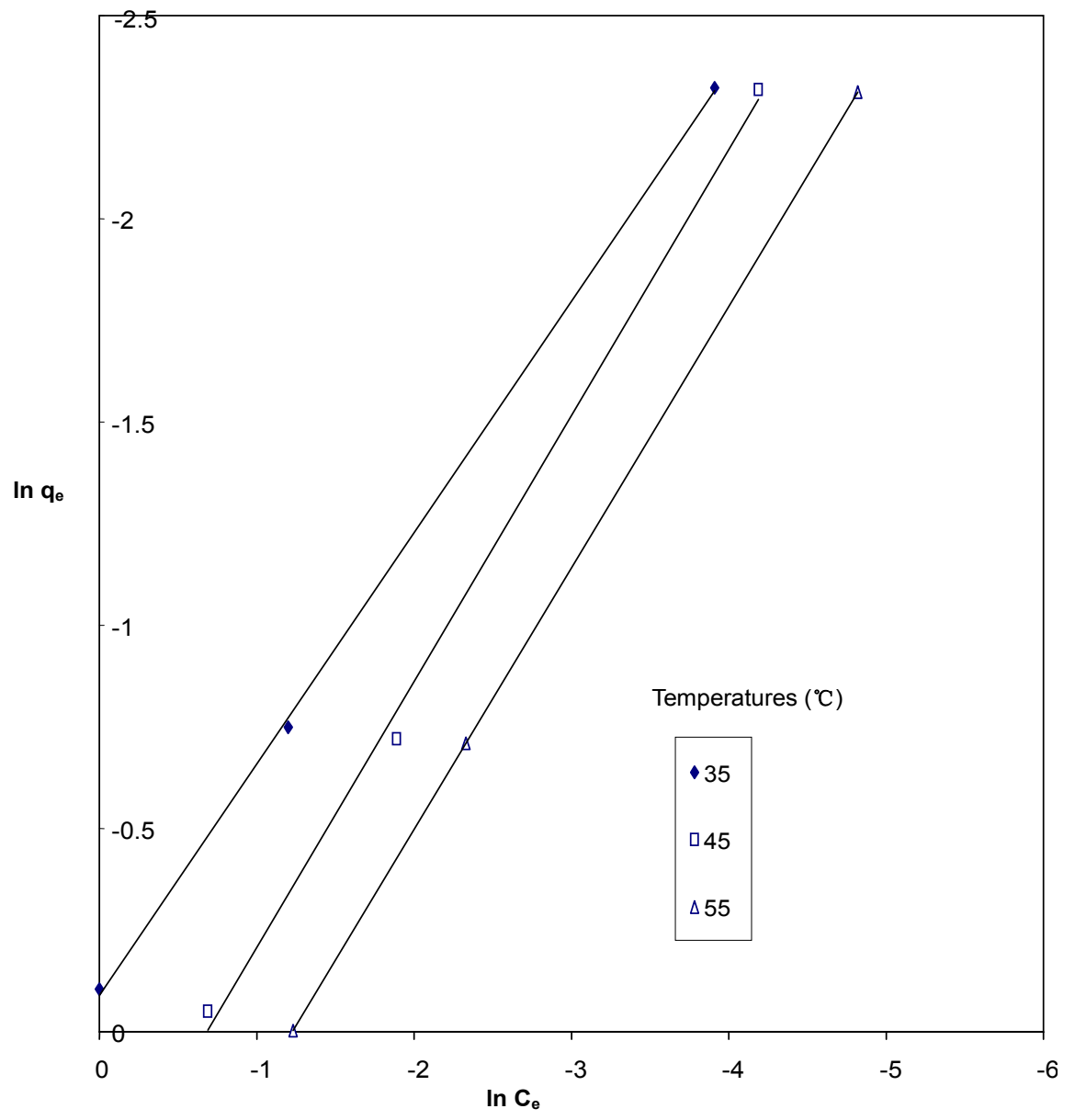

Figure 5. Freundlich isotherm for adsorption of malathion on fly ash at different temperatures. pH: 4.50 , particle size: 149 $\mu \mathrm{m}$, agitation speed: $138 \mathrm{rpm}$, Contact time: $90 \mathrm{~min}$. 


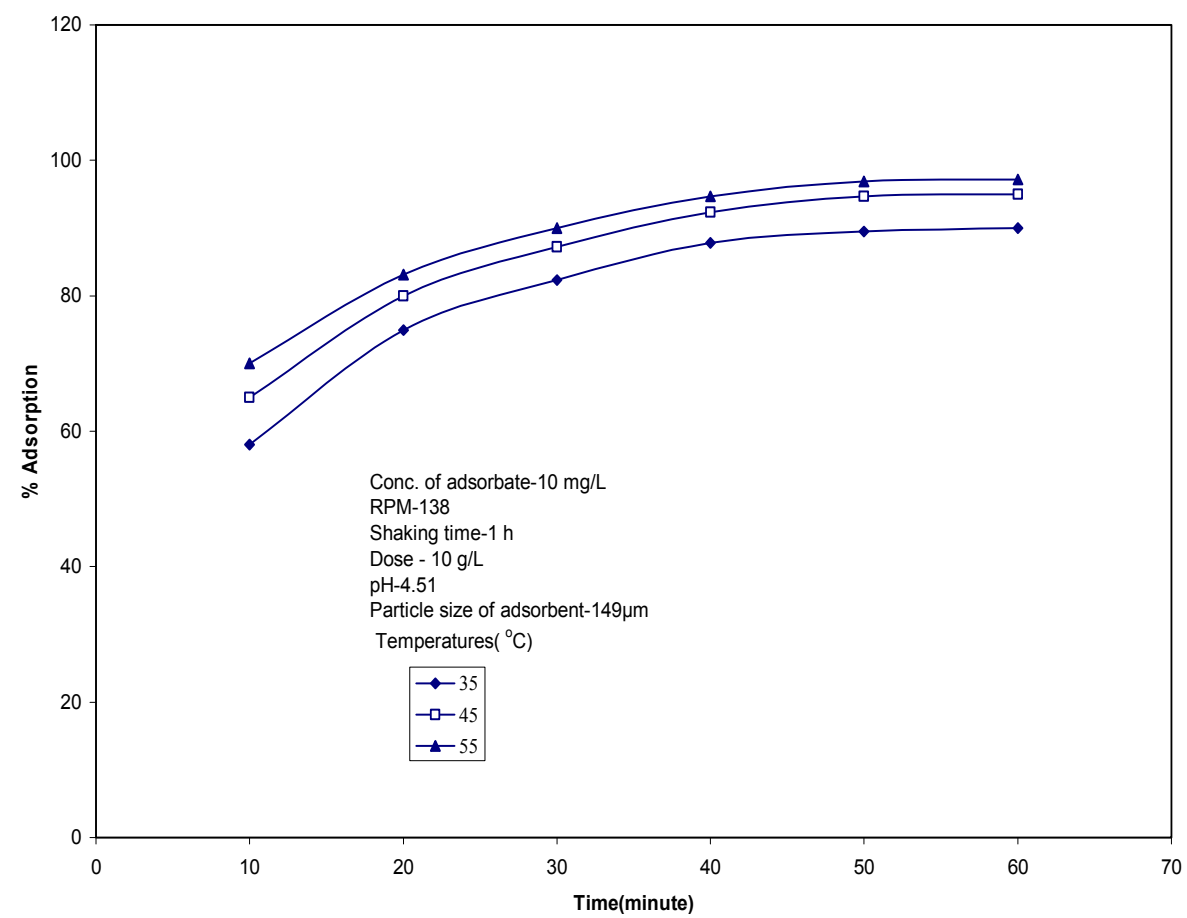

Figure 6. Time variation of adsorption of malathion on fly ash at different temperatures. pH: 4.50 , partical size: $149 \mu \mathrm{m}$, agitation speed: $138 \mathrm{rpm}$, initial concentration: $10 \mathrm{mg} / \mathrm{L}$.

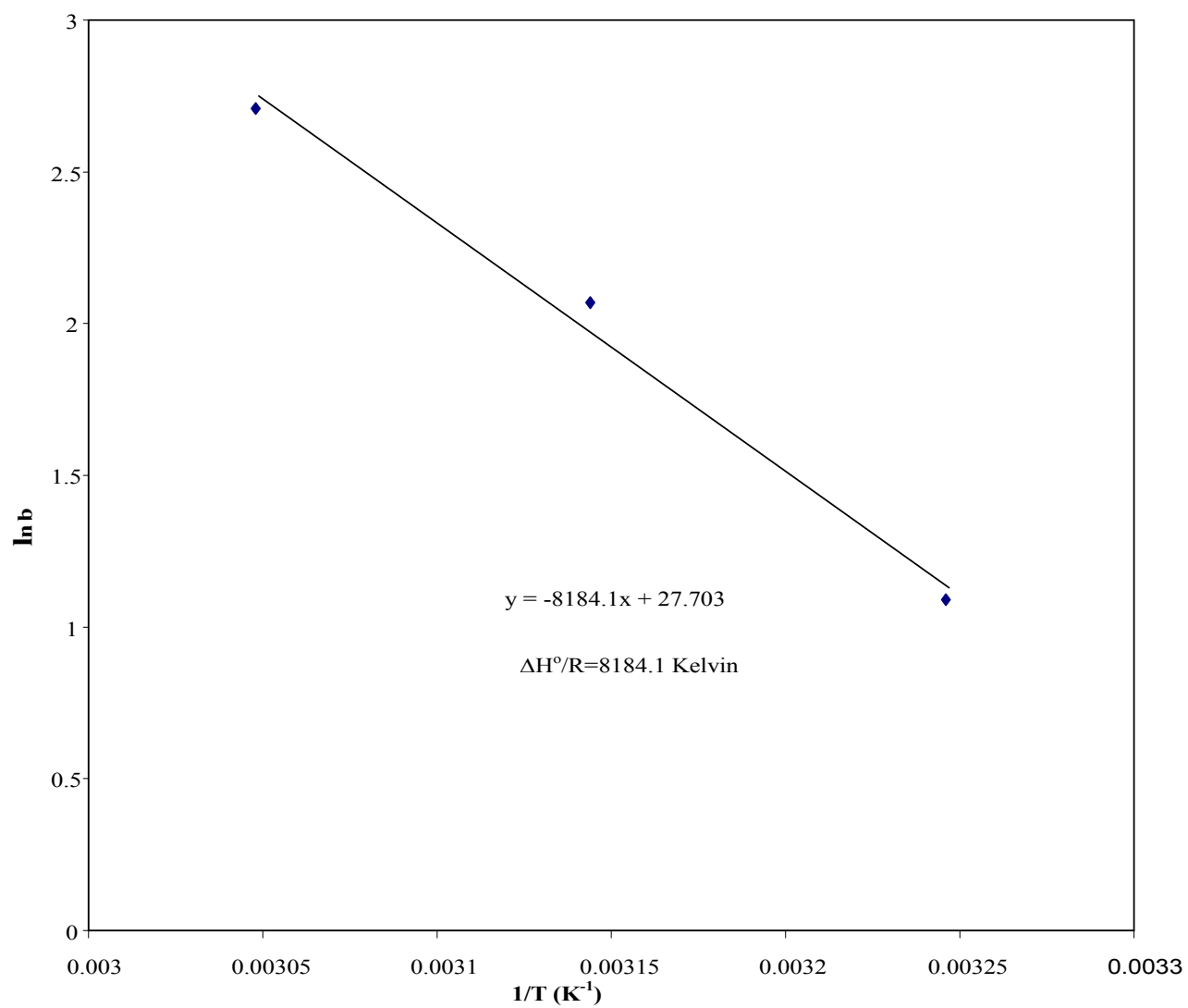

Figure 7. plot of Inb versus 1/T for enthalpy change for the adsorption of malathion on fly ash at different temperatures. pH: 4.50, particle size: $149 \mu \mathrm{m}$, agitation speed: $138 \mathrm{rpm}$, contact time: $90 \mathrm{~min}$. 
was observed in low concentration ranges and this finding has industrial importance as in wastewaters, the concentration of malathion is in low ranges. The process of removal has been optimized for various parameters affecting the removal.

The data generated can serve as baseline data for designing treatment plants for the treatment of malathion containing effluents/wastewaters.

\section{References}

[1] L. Ehrenberg, Jensen and A. K. Kaul, "Residues of Some Organoclorine Pesticides in Indian Foods," Everyman's Science, Vol. 11, 1976, pp.163-165.

[2] B. S. Kaphalia, A. Siddiqui and T. D. Seth, "Contamination Levels in Different Food Items and Dietary in Take of Organochlorine Pesticide Residue in India," Indian Journal Medical Research, Vol. 81, 1975, pp. 71-77.

[3] V. Krishnamoorthy, Ruplal and N. Rao, "Pesticide Residue in Food: An Overview of Studied under Taken in India," Consumer Education Research Center, Ahmedabad, 1989, pp. 99-104.

[4] J. P. Jani, C. V. Rajani, J. S. Ministry et al., "Residue of Organochlorine Pesticides and Polycyclic Aromatic Hydrocarbons in Drinking Water of Ahmedabad City, India," Bull Environmental Contamination and Toxicology, Vol. 47, No. 3, September 1991, pp. 381-387.

[5] S. Kumar and K. P. Singh, "Comparative Profile of Contaminants in Ground Water and Surface Water Sources in Khasi Hills," Indian Journal of Environment Protection, Vol. 13, 1997, pp. 349-357.

[6] S. Kumar, K. P. Singh and K. Gopal, "Organochlorine Residues in Rural Drinking Water Sources of Northern and North Eastern India," Journal of Environmental Science and Health, Vol. 30, No. 6, July 1995, pp. 1211-1222.

[7] P. C. Abhilash and N. Singh, "Pesticide Use and Application: An Indian Scenario," Journal of Hazardous Materials, Vol. 165, No. 1-3, June 2009, pp.1-12.

[8] S. B. Agrawal, "A Clinical Biochemical Neurobehavioral and Sociopsychological Study of 190 Patients Admitted to Hospital as a Result of Acute Organophosphorus Poisoning," Environmental Research, Vol. 62, No. 1, July 1993, pp. 63-67.

[9] E. Vilanova and M. A. Sogorb, "The Role of Phosphotriesters in the Detoxication of Organophosphorus Compounds," Critical Reviews in Toxicology, Vol. 29, 1999, pp. 21-57.

[10] C. J. Wang and Z. Q. Liu, "Foliar Uptake of Pesticides-Present Status and Future Challenge," Pesticide Biochemistry and Physiology, Vol. 87, 2007, pp 1-8.

[11] D. C. Adams and L. T. Watson, "Treatability of S-triazine Herbicide Metabolites Using Powdered Activated Carbon," Journal of Environmental Engineering, Vol. 122, No. 4, April 1996, pp 327-330.

[12] H. Jiang, C. Adams, N. Grazino, A. Roberson, M. Mac Guire and D. Khiari, "Occurrence and Removal of
Chloro-s-triazine in Water Treatment Plants," Environmental Science and Technology, Vol. 40, No. 11, 2006, pp. 3609-3616.

[13] M. V. Lopez-Ramon, M. A. Fontecha-Camara, M. A. Alvarez-Merino and C. Moreno-Castilla, "Removal of Diuron and Amitrol from Water under Static and Dynamic Conditions Using Activated Carbon in Form of Fiber, Cloth and Grains," Water Research, Vol. 41, No. 13, 2007, pp. 2865-2870.

[14] Y. Sudhakar and A. K. Dikshit, "Adsorbent Selection for Endosulfan Removal from Waste Water Environment," Journal of Environmental Science and Health, Part B, Vol. 34, No. 1, January 1999, pp. 97-118.

[15] M. Akhtar, S. M. Hasany, M. I. Bhanger and S. Iqbal, "Low Cost Sorbent for the Removal of Methyl Parathion Pesticide from Aqueous Solution," Chemosphere, Vol. 66, No. 10, January 2007, pp.1829-1838.

[16] H. E. Bakouri, J. Morillo, J. Usero and A. Quassini, "Potential Use of Organic Waste Substances as an Ecological Technique to Reduce Pesticide Groundwater Contamination," Journal of Hydrology, Vol. 353, No. 3-4, May 2008, pp.335-342.

[17] H. E. Bakouri, J. Morillo, J. Usero and A. Quassini, "Natural Attenuation of Pesticide Water Contamination by Using Ecological Adsorbents: Application for Chlorinated Pesticides Included in European Water Framework Directives," Journal of Hydrology, Vol. 364, No. 1-2, 2009, pp. 175-181.

[18] S. Boudesocque, E. Guillon, M. Aplincourt, F. Martel and S. Noael, "Use of a Low-Cost Biosorbents to Remove Pesticides from Waste Water," Journal of Environmental Quality, Vol. 37, 2008, pp. 631-638.

[19] U. Traub-Eberhard, K. P. Hensche, W. Kordel and W. Klein, "Influence of Different Field Sites on Pesticide Movement into Subsurface Drain," Pesticide Science, Vol. 43, No. 2, 1995, pp. 121-129.

[20] N. Singh, "Adsorption of Herbicides on Coal Fly Ash from Aqueous Solutions," Journal of Hazardous Materials, Vol. 168, No. 1, 30 August 2009, pp.233-237.

[21] Y. C. Sharma, Uma, S. N. Singh, Paras and F. Gode, "Fly Ash for the Removal of Mn(II) from Aqueous Solutions and Wastewaters," Chemical Engineering Journal, Vol. 132, No. 1-3, 1 August 2007, pp. 19-323.

[22] S. Lagergren, "Zur Theorie der Sogenannten Adsorption Gelöster Stoffe, Kungliga Svenska Vetenskapsakademiens," Handlingar, Vol. 24, No. 4, pp. 1-39.

[23] M. Yavuz, F. Gode, E. Pehlivan, S. Ozmert and Y. C. Sharma, "An Economic Removal of $\mathrm{Cu}^{2+}$ and $\mathrm{Cr}^{3+}$ on the New Adsorbents: Pumice and Polyacrylonitrile/Pumice Composite," Chemical Engineering Journal, Vol. 137, No. 3, 15 April 2008, pp. 453-461.

[24] A. K. Singh, D. P. Singh, K. K. Pandey and V. N. Singh, "Wollastonite as Adsorbent for Removal of Fe(II) from Water," Journal of Chemical Technology and Biotechnology, Vol. 42, No. 1, 1988, pp. 39-49.

[25] K. Bhattacharya and C. Venkobachar, "Removal of Cadmium(II) by Low Cost Adsorbents," Journal of Environ- 
mental Engineering, Vol. 110, No. 1, 1984, pp. 110-122.

[26] K. K. Pandey, G. Prasad and V. N. Singh, "Use of Wollastonite for Treatment of $\mathrm{Cu}$ (II) Rich Effluents," Water Air and Soil Pollution, Vol. 27, No. 3-4, February 1986, pp. 287-296.

[27] V. K. Singh and P. N. Tiwari, "Removal and Recovery of Cr(VI) form Industrial Waste Water," Journal of Chemical Technology and Biotechnology, Vol. 69, No. 3, 1997, pp. 376-382.

[28] Y. C. Sharma, Uma, S. Singh, et al., "Fly ash for the Removal of $\mathrm{Mn}(\mathrm{II})$ from Aqueous Solutions and Wastewa- ters," Chemical Engineering Journal, Vol. 132, No. 1-3, August 2007, pp. 319-323.

[29] Y. C. Sharma, "Thermodynamics of the Removal of Cadmium by Adsorption on an Indigenous Clay," Chemical Engineering Journal, Vol. 145, No. 1, December 2008, pp. 64-68.

[30] Y. C. Sharma, S. N. Kaul and C. H. Weng, "Adsorptive Separation of Cadmium from Aqueous Solutions and Wastewaters by Riverbed Sand," Environmental Pollution, Vol. 150, No. 2, November 2007, pp. 251-257. 